\title{
Levels of Empathy among Dental Students in Five Chilean Universities
}

\author{
Víctor Patricio Díaz-Narváez1,2*, Aracelis Calzadilla Núñez³, Doris Carrasco4, Alex Bustos5, \\ Alejandro Zamorano6, Henry Silva6, Elizabeth López Tagle7, Joyce Hubermann' ${ }^{8}$, \\ Robert Utsman', Alejandro Reyes Reyes ${ }^{10}$ \\ ${ }^{1}$ Faculty of Dentistry, Universidad San Sebastián, Santiago, Chile \\ ${ }^{2}$ Universidad Autónoma de Chile, Santiago, Chile \\ ${ }^{3}$ Department of Child and Adolescent Psychiatry, Felix Bulnes Hospital, Santiago, Chile \\ ${ }^{4}$ Department of Restorative Dentistry, School of Dentistry, Universidad de Concepción, Concepción, Chile \\ ${ }^{5}$ Department of Prevention and Public Health, Faculty of Dentistry, Universidad de Concepción, Concepción, \\ Chile \\ ${ }^{6}$ School of Dentistry, Universidad Finis Terrae, Santiago, Chile \\ ${ }^{7}$ School of Dentistry, Universidad Andrés Bello, Santiago, Chile \\ ${ }^{8}$ School of Dentistry, Faculty of Medicina-Clínica Alemana, Universidad del Desarrollo, Santiago, Chile \\ ${ }^{9}$ School of Health Sciences, Universidad Latinoamericana de Ciencia y Tecnología (ULACIT), San José, \\ Costa Rica \\ ${ }^{10}$ School of Psychology, Universidad Santo Tomas, Concepción, Chile \\ Email: *victor.diaz@uss.cl, araceliscalza@gmail.com,doriscarrasco@udec.cl, abustos@udec.cl, \\ azamorano@uft.cl, hensilurday@gmail.com, elizabethlopez@unab.cl,jhuberman@udd.cl, \\ rutsman@ulacit.ac.cr, alejo_reyes_reyes@hotmail.com
}

Received 21 November 2015; accepted 10 January 2016; published 13 January 2016

Copyright (C) 2016 by authors and Scientific Research Publishing Inc.

This work is licensed under the Creative Commons Attribution International License (CC BY). http://creativecommons.org/licenses/by/4.0/

(c) (i) Open Access

\begin{abstract}
Aim: To compare empathic levels among dental students of five Dental Faculties in Chile. Material and Methods: Empathic orientation of dental students was measured using the Jefferson Scale of Physician Empathy, the Spanish version for students (S version), validated in Chile and culturally adapted to dental students. The data were compared using analysis of variance trifactorial (model III) and by a discriminant analysis. Results: It was found that differences exist between universities empathic orientation, courses, and gender. Conclusions: The results showed a great variability of empathetic guidance values on the factors studied. Discriminant test confirm the similarity and differences found among faculties from the data matrix provided by the scale used. It is not possible in this investigation to explain the variability found.
\end{abstract}

\footnotetext{
${ }^{*}$ Corresponding author.
}

How to cite this paper: Díaz-Narváez, V.P., Núñez, A.C., Carrasco, D., Bustos, A., Zamorano, A., Silva, H., Tagle, E.L., Hubermann, J., Utsman, R. and Reyes, A.R. (2016) Levels of Empathy among Dental Students in Five Chilean Universities. Health, 8, 32-41. http://dx.doi.org/10.4236/health.2016.81005 


\section{Keywords}

\section{Empathy, Jefferson Scale of Physician Empathy, Empathic Levels, Empathy Components}

\section{Introduction}

Hojat et al. [1] indicate that empathy attributes are important in medical practice associated with: pro-social behavior, respect, positive attitudes toward the elderly, moral reasoning, the absence of malpractice, the ability to collect clinical history and proper execution of the physical examination, satisfaction of patient and physician, the best therapeutic relationship and good clinical results. In another dimension, Stephenson et al. [2] argue that educational and professional organizations have noted with emphasis the need to study and introduce empathy, not only in the formation of doctors, but also in those who are already engaged in practice, as an essential aspect of their professionalism in the workplace. Furthermore, Díaz et al. [3] found that there are differences within a country and between countries when data matrices are observed and with the application of the Jefferson Scale of Physician Empathy (JSPE), which is consistent with the multidimensional structure of empathy [4]. Empathy is defined based on three dimensions: 1) perspective taking; 2) care with compassion and 3) ability to "step into the shoes of the patient" [5].

The results of the data observed in several schools of dentistry, medicine and kinesiology appear to be contradictory in relation to the study of at least two factors: course in which the student is enrolled and gender [3]. Part of the explanation for this diversity of results might be due to the varying components of empathy [5], maybe, in turn influenced by other variables that affect the structure of the dimensions (components) described above. Thus, studies of Roh et al. [6] and Kataoka et al. [7] show that there are differences between countries (Korea and Japan respectively). These differences could be attributed to the existence of diverse cultures and education of medical practice itself [7] [8].

According to Silva et al. [8], these differences could open a "research gap in relation to the socio-cultural implications that could affect empathy levels of health professionals in training". Other authors [3] [9]-[11] arrived at the same conclusions. Since there is diversity of outcomes in relation to the assessment and evaluation of the variable empathy in different contexts and scales, in some cases, the same factors, the objective of this study is to estimate and compare the levels of empathy in students of five dental faculties (six schools) located in different regions of Chile.

\section{Materials and Methods}

This investigation, exploratory, not experimental, descriptive, cross-sectional and ex post facto cause-effect [12], bio ethically governed by the rules of Helsinki, (approved by the Ethics Committee of Research, University of Desarrollo: Resolution 2011-64) consist of student populations belonging to levels of first, second, third, fourth and fifth year of the career of Dentistry at the Dental Faculties of the University of Andrés Bello (Santiago site and Viña del Mar, central location), University of Antofagasta (north location), University Finis Terrae (central location), University of Desarrollo (Santiago site, central location) and University of Concepción (south location), all located in the Republic of Chile. Data collection was conducted from June to July 2013, almost simultaneously in each of the faculties mentioned above. All participating institutions and students (letter of consent) approved the completion of this investigation and the publication of results (exclusion criterion). The sample consisted of all those individuals who could be evaluated on the day that it corresponded, on a voluntary basis and a signed letter of consent (exclusion criteria). All students, upon the application of the scale, were attending the last section of the first semester of each course. The participants of each of the samples were applied the Jefferson Scale of Physician Empathy, the Spanish version for students (S version), validated in Mexico and Chile [13] and culturally adapted to Chile, by the Criteria Board [13] (Appendix 1). There were no other exclusion criteria, since the object was to evaluate the variable of interest in the greatest amount of students possible. Consistent with the aforementioned, a single anonymous and confidential measure was first performed, by neutral operator, to students from first to fourth year students in classrooms. In the case of fifth year students the instrument was administered on a visit to the clinical setting, with the same indications previously mentioned.

The summation scores of the raw data obtained, in scale previously mentioned, was initially submitted to the 
normality test of Shapiro-Wilk [14] and homogeneity of Levene [15] in the three factors studied: University, Course (Year) and Gender. The descriptive statistics were estimated; arithmetic mean and standard deviation (including outliers) in all factors and their corresponding levels. The comparison of means within the levels of the main factors studied were performed using a General Linear Model Univariate (ANOVA) Tri-factor model III and multiple comparison test of Duncan, for unbalanced data in accordance with Diaz [12]. Observed power (1- $\beta$ ) and the effect size was evaluated [12] [16]. Statistician's estimates are drawn on a profile graph. Subsequently a discriminant analysis was realized, based on the values of the answers of each question contained in the JSPE scale, taken together as independent variables; therefore, each question of the scale was established on a "variable" of an array of variables and subjects. The Wilks $\lambda$ distribution [17] was used in order to measure the proportion of the total variance of the discriminant scores not explained by differences in universities. To test whether the variance and covariance matrices of each University (School of Dentistry) come from or not the same population, Box's M test was used [17] [18]. Eigenvalues were estimated [15]. Data were analyzed using the SPSS 20.0 statistical program. The level of significance was set at $\alpha \leq 0.05$ and $\beta \leq 0.05$ in all cases.

\section{Results}

The total number of students who were tested was $n=1722$, broken down as follows: University of Antofagasta: 204, Andres Bello University (Santiago site): 447, Finis Terrae: 309, University Andres Bello (Viña del Mar site): 307, the University of Desarrollo (Central location Santiago): 318, and the University of Concepción: 341. In Table 1 the results of applying a tri-factorial model are presented. It was observed that the factors "University", "Gender" were highly significant $(p<0.005)$ and the factor "Course" was significant $(p<0.05)$ which indicates differences between faculties (including two sites of the same faculty), among courses and between genres, but no interaction of any order (types of interactions) were significant ( $p>0.05$ ). However, $\eta^{2}$ statistic, which indicates the size of the effect of the "treatment" studied, is small (0.013, 0.006 and 0.009$)$, all of which can be interpreted as there are differences between the factors analyzed, but they are not great. The power of the test, in all cases, are above the permissible minimum: 0.80 , with the exception of course factor $(0.776)$ where it is assumed that the risk of making a Type II error is higher than desired. As a result, the differences or similarities found should be examined with caution, in the sense that they exist, but are of small magnitude $\left(\mathrm{R}^{2}=0.032\right)$.

Table 2 shows the mean values of the Dental Faculties of each University studied. It is observed that the mean of the University of Antofagasta is the lowest of all, followed in ascending order by the Andres Bello University (Central location Santiago), Finis Terrae, Andrés Bello (Viña del Mar Site), University of Desarrollo and, finally, the University of Concepcion which was characterized for having the highest values of empathic orientation. The standard error is small and indicates that the averages are well centered.

In Table 3 the results are shown by course. A steady increase from first to fifth year is observed, except for the fourth year, which as pointed out before in this year the course ascent is interrupted. In Table 4 the results are

Table 1. Results of analysis of variance (Model III) values of empathic orientation in all factors studied.

\begin{tabular}{cccccccc}
\hline Origen & $\begin{array}{c}\text { Sum of Type III } \\
\text { Squares }\end{array}$ & gl & Root Mean Square & F & Sig. & Partial Square Eta & Observed Power \\
\hline University & 4317.323 & 5 & 863.465 & 5.001 & $\mathbf{0 . 0 0 0}$ & 0.013 & 0.985 \\
Course & 1959.252 & 4 & 489.813 & 2.837 & $\mathbf{0 . 0 2 3}$ & 0.006 & 0.776 \\
Genre & 3031.949 & 1 & 3031.949 & 17.560 & $\mathbf{0 . 0 0 0}$ & 0.009 & 0.987 \\
University * Course & 3365.185 & 20 & 168.259 & 0.974 & 0.491 & 0.010 & 0.756 \\
University * Genre & 719.231 & 5 & 143.846 & 0.833 & 0.526 & 0.002 & 0.303 \\
Course * Genre & 768.830 & 4 & 192.208 & 1.113 & 0.349 & 0.002 & 0.354 \\
University * Course * Genre & 2905.987 & 20 & 145.299 & 0.842 & 0.664 & 0.009 & 0.673 \\
Error & $322,196.401$ & 1866 & 172.667 & & & & \\
Total & $24,921,154.000$ & 1926 & & & & &
\end{tabular}


Table 2. Results of the estimates of the mean, standard error and confidence interval of the observed data of empathic orientation in the dental faculties of Chilean universities studied.

\begin{tabular}{ccccc}
\hline Dental Faculties of Universities & Mean & Standard Error & Confidence Level of 95\% \\
\cline { 4 - 5 } & & & Lower Limit & Upper Limit \\
\hline University of Antofagasta & 110.629 & 0.957 & 108.751 & 112.506 \\
University of Desarrollo & 113.676 & 0.792 & 112.123 & 115.230 \\
Finis Terrae University & 111.997 & 0.813 & 110.402 & 113.591 \\
Andrés Bello University (Viña del Mar site) & 113.040 & 0.883 & 111.308 & 114.772 \\
Andrés Bello University (Santiago site) & 111.810 & 0.669 & 110.498 & 113.123 \\
University of Concepción & 115.758 & 0.750 & 114.286 & 117.229 \\
\hline
\end{tabular}

Table 3. Result of the estimates of the mean, standard error and confidence interval of the observed data of empathic orientation in each of the courses regardless of the Dental Faculty and Chilean university studied.

\begin{tabular}{ccccc}
\hline & Mean & Standard Error & \multicolumn{2}{c}{ Confidence Level of 95\% } \\
\cline { 3 - 4 } Course & & Lower Limit & Upper Limit \\
\hline First & 111.310 & 0.643 & 110.048 & 112.572 \\
Second & 111.897 & 0.656 & 110.611 & 113.183 \\
Third & 113.630 & 0.743 & 112.173 & 115.087 \\
Fourth & 112.820 & 0.756 & 111.336 & 114.303 \\
Fifth & 114.435 & 0.898 & 112.674 & 116.197 \\
\hline
\end{tabular}

Table 4. Results of the estimates of the mean, standard error and confidence interval of the observed data of empathic gender orientation regardless of the Dental Faculty and Chilean university studied.

\begin{tabular}{ccccc}
\hline \multirow{2}{*}{ Genre } & Mean & Standard Error & \multicolumn{2}{c}{ Confidence Interval of 95\% } \\
\cline { 3 - 4 } & & & Lower Limit & Upper Limit \\
\hline Feminine & 114.214 & 0.413 & 113.405 & 115.024 \\
Masculine & 111.422 & 0.523 & 110.396 & 112.448 \\
\hline
\end{tabular}

shown for the genres studied. The female genre shows a higher average than men and, as reflected in Table 1, there are statistical differences, but with the effect of small sample size.

In Table 5 the results of multiple comparison of means by Duncan among universities are observed. It was found that four groups are formed. The first consists of the means of the University of Antofagasta, Andrés Bello (Santiago site) and Finis Terrae University, among which there are no significant differences ( $p>0.05)$. In the second group are the means of the University Andres Bello (Santiago site), Finis Terrae and Andres Bello University (Viña del Mar site), among which there are no significant differences ( $p>0.05)$; however, the average of Andres Bello University (Viña del Mar site) differed significantly $(\mathrm{p}<0.05)$ from the University of Antofagasta. The third group was constituted by the means of Finis Terrae University, Andres Bello (Viña del Mar site) and the University of Desarrollo of which there are no significant differences ( $>>0.05)$; however, the University of Desarrollo differed significantly $(\mathrm{p}<0.05$ ) with Andres Bello University (Santiago site) and the University of Antofagasta. The fourth and last group, consists of the University of Desarrollo and the University of Concepcion, among which there are no significant differences ( $p>0.05$ ); however, the University of Concepción differs significantly with all $(\mathrm{p}<0.05)$, except, as noted, with the University of Desarrollo.

In Table 6 the results of multiple comparison of means between courses are observed. In the first group comprised of first and second year courses, there are no statistical differences observed between them $(\mathrm{p}>0.05)$. A 
Table 5. Results of the comparison between the mean values of empathic orientation between the universities studied.

\begin{tabular}{|c|c|c|c|c|c|}
\hline \multirow{2}{*}{ Dental Faculties of Universities } & \multirow{2}{*}{$\mathrm{N}$} & \multicolumn{4}{|c|}{ Subset } \\
\hline & & 1 & 2 & 3 & 4 \\
\hline University of Antofagasta & 204 & 110.35 & & & \\
\hline Andrés Bello University (Santiago Site) & 447 & 111.51 & 111.51 & & \\
\hline Finis Terrae University & 309 & 112.35 & 112.35 & 112.35 & \\
\hline Andrés Bello University (Viña del Mar Site) & 307 & & 112.68 & 112.68 & \\
\hline University of Desarrollo & 318 & & & 114.37 & 114.37 \\
\hline University of Concepción & 341 & & & & 115.94 \\
\hline Sig. & & 0.076 & 0.301 & 0.072 & 0.143 \\
\hline
\end{tabular}

Table 6. Results of the comparison between the mean values of empathic orientation between courses regardless of the Dental Faculty at the university studied.

\begin{tabular}{ccccc}
\hline & & & Subset & \\
Course & $\mathrm{N}$ & 1 & 2 & \\
\cline { 3 - 4 } & & 111.66 & & \\
First & 504 & 111.94 & 111.94 & 113.82 \\
Second & 454 & & 113.82 & 113.97 \\
Fourth & 343 & & & 114.72 \\
Third & 357 & & & 0.386 \\
Fiifth & 268 & 0.767 & 0.054 & \\
Sig. & & & & \\
\hline
\end{tabular}

second group formed by the means of the second and fourth year courses, no significant differences are observed between them ( $p>0.05)$; however, the means of the fourth year differed significantly $(p<0.05)$ from the first year. Finally, a third group, formed by the means of the fourth, third and fifth year courses, resulted in no significant differences between them $(p>0.05)$; however, the mean of third and fifth year differ significantly $(p<0.05)$ from first and second year courses.

The results observed for the M Box test of the canonical discriminant functions was $\chi^{2}=157,909 ; \mathrm{F}=75 ; \mathrm{p}<$ 0.0005 , all of which show that the covariance matrices are different. The observed values $\lambda$ of Wilks were highly significant; which indicates that there is no variance explained by the difference between some of the universities analyzed. Measuring the eigenvalues found that most of the accumulated variance is between discriminant functions $(73.6 \%)$.

\section{Discussion}

The results observed of the levels of empathy and comparison of their respective means and arrays of values of scales applied between dental faculties studied in Chile, found the following: 1) there are differences between some of the dental faculties of the universities studied; 2) the female gender, in general, has higher levels of empathic orientation than males; 3) there is a tendency of increased levels of empathic orientation as students advance in the course for which has elapsed; however, it became clear that the means of the courses within and between each university tend to be different, but these differences are not homogeneous in both genders analyzed. There appears a tendency of greater dispersion between and within the means of the female gender in relation to male, all of which should be the subject of further work to verify this finding and 4) no interactions between the factors studied were observed.

These results are consistent, different, or even, contradictory with those observed in other studies [8] [19]-[27] made in Latin America. In relation to other contexts, results also reflected consistent, different, or even, contra- 
dictory [28]-[34] and also between countries [3] [6] [7]. The above, represents a consistent trend [3] in the sense that the variability seems to be the rule in the measurement of empathic orientation and how the measurement of empathy can be reflected in their evaluation by factorial studies. These findings corroborate the working hypothesis [35] in several underlying investigations [1]-[8] consistent with the concept of empathy, in terms of structure of the components described previously [5], that dimensions are dependent on many factors and it is precisely these that modulate or interact, and therefore, finally explain or help to explain the measured values of empathic orientation and of own empathy construct.

Therefore, what we are actually measuring with the applied scale is the result of a complex process and, moreover, is built evolutionarily [36] possibly from the embryonic formation to maturity of a subject. As a result, the explanation of the variability in relation to empathy is a complex problem [3]. Since it is not possible to cover all aspects related to the "determination" of the levels of empathy, the plausibility of the indicated hypothesis, could be evaluated theoretically from what is involved in the process of teaching-learning in Higher Education [2] [3], in relation to professional training and its potential future impact on patient care and the perception that this has on the doctor, in particular, professionals of Health Sciences, in general, regarding the satisfaction, confidence and complacency [37]. In this process it is possible to introduce programs that collaborate with the development of empathy in students of Health Sciences in general. As a result, from a curricular point of view, it is important to put more emphasis on training of generic skills associated with dentist-patient relationship and include vital variables in curriculum of the respective faculties; besides, the role of teachers as an empathetic model (and other generic skills) that plays an important role in formation of the student.

As it was previously mentioned, universities constitute an important part of the social responsibility of the commitment to train integral professionals, taking advantage of the "biological" opportunity of the students, mostly, young adults and their evolving brains provide windows of evolutionary opportunities [3]. The rationale for the existence of these "windows" can; on the one hand, be associated with the development of neural empathy studies (functional neuroimaging) have found that affective, cognitive and regulatory components of empathy show an interaction of neural circuits [38], “...mediated by bidirectional connections between the brain stem, the amygdala and the sensory cortex, as well as connections to the hypothalamus, insula and somatosensory cortex" [39] [40] and, furthermore, the theory of mind and the theory of mirror neurons, which attempt to explain the origin of empathy, theories adequately clarified by Howard et al. [21] and do not need to be repeated at length in this paper. The first theory provides the ability to hypothesize about feelings and thoughts, and thereby, interpret the behavior of a subject. Mirror neurons fire when an action is performed or watching someone else do it [41] [42]. The mirror neurons, also, allow socialization to promote understanding of others through feelings [43], while the theory of mind seeks to explain the nature of cognitive empathy [44]. Of course, neural connections are the biological basis of development of the components of the above mentioned, empathy. These components are susceptible to develop until an adult age. These components are likely to develop until a young adult age.

However, as many authors have discussed, the role of empathy, as part of medical education [38] in general, and in dentistry, in particular, is less clear [21] [45]. There are researchers who disagree with the fact that empathy can change with the educational intervention [5] [46], while other authors suggest that empathy can be learned and that doctor-patient relationship, the medical ability to help relieve pain, possessing medical knowledge to help, the doctor in a hierarchical position relative to the patient are aspects that seem to be learned [5] [47] [48].

Decety et al., [49] specifically state that the current perspective of empathy in clinical practice is limited due to three possible causes: it focuses primarily on self-reporting by physicians, poor understanding of the mechanisms contributing to the decline empathy during medical studies and tendency to have lack of empathy among general medical staff. Moreover, the links between cognition, language, family experience and empathy involve a connection between the sensitivity of emotional cues and the development of social cognition [46], all of which clearly show that empathy is closely tied to social cognition and is built on a complex dialectical relationship between the micro and macro system which moves the individual [3] and no student of dentistry or health sciences, is exempt from this relationship. Therefore, the study of empathy under the focus of the vulnerability to risk (factors that explain the observed levels of empathy), help build a curriculum that will improve empathy in dentistry and health sciences in general.

The aim of this study was to estimate and compare the levels of empathy among dental students in five faculties (including two sites of the same faculty) located in different regions of Chile, the reason in which we find differences and similarities, but we cannot explain why this situation occurs. From the point of view strictly associated with medical education, it is possible to argue that the findings could be explained by different factors in- 
fluencing the structuring of empathy and one of them could be the content and curricular structure of the curriculum. The variability found, on the one hand, could lead to the need to understand the mechanisms involved in empathy, interpersonal sensitivity and behavior in front of the patient and, secondly, the strict understanding of the factors influencing and how they specifically influence "determination" of empathy levels of a specific faculty. However, gender factor could be a source of variation as has been demonstrated by Diaz-Narvaez et al. [50].

Consequently, the question: What are all the factors responsible for these differences and similarities and how exactly they modulate the formation of empathy?, has been answered only in terms of its "initial moment": a "diagnosis" of the situation and it’s specific answer will require further research.

\section{Aknowledgements}

We thank Drs. Horacio Gonzalez, Dean of the Faculty of Medicine and Dentistry, and Dr. Victor Aravena, Director of the School of Dentistry, Faculty of Medicine and Dentistry at the University of Antofagasta; whom applied the scale to their students and selflessly provided the data to carry out this study.

\section{Competing Interests}

The authors declare that they have no competing interests.

\section{Financing}

Research funded by the authors.

\section{Ethical Approval}

The investigation was bio ethically governed by the rules of Helsinki, and approved by the Ethics Committee of Research, University of Desarrollo: Resolution 2011-64.

\section{References}

[1] Hojat, M., Gonella, J.S., Nasca, T.J., Mangione, S., Vergare, M. and Magee, M. (2002) Physician Empathy: Definition, Components, Measurement and Relationship to Gender and Specialty. American Journal of Psychiatry, 159, 15631569. http://dx.doi.org/10.1176/appi.ajp.159.9.1563

[2] Stephenson, A., Higgs, R. and Sugarman, J. (2001) Teaching Professional Development in Medical Schools. Lancet, 357, 867-870. http://dx.doi.org/10.1016/S0140-6736(00)04201-X

[3] Díaz-Narváez, V.P., Alonso, L.M., Caro, S.E., Silva, M.G., Arboleda, J., Bilbao, J.L. and Iglesias, J. (2014) Empathic Orientation among Medical Students from Three Universities in Barranquilla, Colombia and One University in the Dominican Republic. Archivos Argentinos de Pediatría, 112, 41-49.

[4] Kunyk, D. and Olson, J.K. (2001) Clarification of Conceptualizations of Emphaty. Journal of Advanced Nursing, 35, 317-325.

[5] Alcorta-Garza, A., González-Guerrero, J.F., Tavitas-Herrera, S.E., Rodríguez-Lara, F.J. and Hojat, M. (2005) Scale validation of Jefferson Medical Empathy in Mexican Medical Students. Salud Mental, 28, 57-63.

[6] Roh, M., Hahm, B., Lee, D. and Suh, D. (2010) Evaluation of Empathy among Korean Medical Students: A CrossSectional Study Using the Korean Version of the Jefferson Scale of Physician Empathy. Teaching and Learning in Medicine, 22, 167-171. http://dx.doi.org/10.1080/10401334.2010.488191

[7] Kataoka, H., Koide, N., Ochi, K., Hojat, M. and Gonnella, J. (2009) Measurement of Empathy among Japanese Medical Student. Psychometrics and Score Differences by Gender and Level of Medical Education. Academic Medicine, 84, 1192-1197. http://dx.doi.org/10.1097/ACM.0b013e3181b180d4

[8] Silva, M.G., Arboleda, J. and Díaz Narváez, V.P. (2013) Empathic Orientation Dental Students from the Universidad Central del Este. Odontoestomatología, 15, 24-33.

[9] Silva, H., Zamorano, A. and Díaz Narváez, V.P. (2013) Assessment Levels Empathic Orientation Dental Students at the University Finis Terrae de Santiago (Chile). Revista Clínica de Periodoncia, Implantología y Rehabilitación Oral, 6, 130-133.

[10] Huberman, J., Rodríguez, M.P., González, S. and Díaz-Narváez, V.P. (2014) Levels of Empathic Orientation Dental Students of the Universidad del Desarrollo, Santiago (Chile). Revista Clínica de Periodoncia, Implantología y Rehabilitación Oral, 7, 169-174. 
[11] Carrasco, D., Bustos, A. and Díaz, V. (2012) Empathic Orientation in Dentistry Chilean Students. Revista Estomatológica Herediana, 22, 145-151.

[12] Díaz-Narváez, V.P. (2009) Scientific Research Methodology and Biostatistics for Professionals and Students of Health Sciences. 2nd Edition, RiL Editores, Santiago.

[13] Rivera, I., Arratia, R., Zamorano, A. and Díaz Narváez, V.P. (2011) Evaluation of Empathic Orientation Dental Students. Salud Uninorte, 27, 63-72.

[14] Shapiro, S.S. and Wilk, M.B. (1965) An Analysis of Variance Test for Normality (Complete Samples). Biometrika, 52, 591-611. http://dx.doi.org/10.1093/biomet/52.3-4.591

[15] Hair, J.F., Anderson, R.E., Tatham, R.L. and Black, W.C. (2001) Multivariate Analysis. Editorial Prentice-Hall, Madrid.

[16] Frías, M.D., Llobell, J.P. and García, J.F. (2000) Size of Treatment Effect and Statistical Significance. Psicothema, 2, 236- 240

[17] Levy, J.P. and Varela, J. (2003) Multivariate Analysis for the Social Sciences. Pearson Prentice Hall, Madrid, $249-257$.

[18] Visauta, B. (1998) Statistical Analysis with SPSS. Vol. II, McGraw-Hill, Madrid, 135-137.

[19] Sánchez, L., Padilla, M., Rivera, I., Zamorano, A. and Díaz-Narváez, V.P. (2013) Levels of Empathic Orientation Dental Students. Educación Médica Superior, 27, 216-225.

[20] Erazo, A.M., Alonso, L.M., Rivera, I., Zamorano, A. and Díaz Narváez, V.P. (2012) Evaluation of Empathetic Orientation Dental Students in Universidad Metropolitana de Barranquilla (Colombia). Salud Uninorte, 28, $354-363$.

[21] Howard, M., Navarro, S., Rivera, I., Zamorano, A. and Díaz Narváez, V.P. (2013) Measuring the Level of Empathic Orientation in Students of the Faculty of Dentistry, Universidad de Costa Rica. Odovtos, 15, 21-26.

[22] Bilbao, J., Alcócer, A., Salazar, G., Rivera, I., Zamorano, A. and Díaz Narváez, V.P. (2013) Evaluation of Empathic Orientation of Dental Students of Fundación Universitaria San Martín. Puerto Colombia. (Atlántico, Colombia). Salud Uninorte, 29, 34-41.

[23] Gutiérrez, F., Quezada, B., López, M., Méndez, J., Díaz Narváez, V.P., Zamorano, A. and Rivero, I. (2012) Measuring the Level of Empathic Perception of the Students of the Faculty of Dentistry Roberto Beltrán. Universidad Peruana Cayetano Heredia. Revista Estomatológica Herediana, 22, 91-99.

[24] Varela, T., Villalba, R.H., Gargantini, P., Quinteros, S., Villalba, S.V. and Díaz Narváez, V.P. (2012) Levels of Empathic Counseling Students of Dentistry; Universidad Católica de Córdova, Argentina (UCC). Claves de Odontología, 70, $15-22$.

[25] Oviedo, M. (2011) Empathy and Training of Students in the Faculty of Dentistry; Universidad de Carabobo. Tesis doctoral Internet, Universidad Autónoma de Madrid, Madrid, 158. http://biblioteca.universia.net/html_bura/ficha/params/title/empatia-estudiantes-formacion-facultad-odontologia-univer sidad-carabobo/id/55311551.html

[26] Alonso, L.M., Caro, S.E., Erazo, A.M. and Díaz Narváez, V.P. (2013) Evaluation of Empathic Orientation of Medical Students; Universidad del Norte. Barranquilla. (Colombia). Salud Uninorte, 29, 22-33.

[27] Rojas-Serey, A.M., Castañeda-Barthelemiez, S. and Parraguez-Infiesta, R.A. (2009) Empathic Orientation in Students from Two Schools of Kinesiology Chile. Educación Médica, 12, 103-109.

[28] Chen, D., Lew, R., Hershman, W. and Orlander, J. (2007) A Cross-Sectional Measurement of Medical Student Empathy. Journal of General Internal Medicine, 22, 1434-1338. http://dx.doi.org/10.1007/s11606-007-0298-x

[29] Bellini, L. and Shea, J. (2005) Mood Change and Empathy Decline Persist during Three Years of Internal Medicine Training. Academic Medicine, 80, 164-167. http://dx.doi.org/10.1097/00001888-200502000-00013

[30] Chen, J., LaLopa, J. and Dang, D. (2008) Impact of Patient Empathy Modeling on Pharmacy Students Caring for the Underserved. American Journal of Pharmaceutical Education, 72, 40. http://dx.doi.org/10.5688/aj720240

[31] Nunes, P., Willians, S., Sa, B. and Stevenson, K. (2011) A Study of Empathy Decline in Students from Five Health Disciplines during Their First Year of Training. International Journal of Medical Education, 2, 12-17. http://dx.doi.org/10.5116/ijme.4d47.ddb0

[32] Hojat, M., Vergare, M.J., Maxwell, K., Brainard, G., Herrine, S.K., Isenberg, G.A., Veloski, J. and Gonnella, J.S. (2009) The Devil Is Third Year: A Longitudinal Study of Erosion of Empathy in Medical School. Academic Medicine, 84, 1182-1191. http://dx.doi.org/10.1097/ACM.0b013e3181b17e55

[33] Sherman, J. and Cramer, A. (2005) Measurement of Changes in Empathy during Dental School. Journal of Dental Education, 69, 338-345.

[34] Beattie, A., Durham, J., Harvey, J., Steele, J. and McHanwell, S. (2012) Does Empathy Change in First-Year Dental Student? European Journal of Dental Education, 16, e111-e116. 
http://onlinelibrary.wiley.com/doi/10.1111/i.1600-0579.2011.00683.x/full

[35] Díaz-Narváez, V.P. and Calzadilla, A. (2009) The Hypothesis and Scientific Research in the Medical and Biological Sciences. Salud Uninorte, 25, 362-373.

[36] Garaigordobil, M. and García de Galdeano, P. (2006) Empathy in Children 10 to 12 Years. Psicothema, 18, 180-186.

[37] Hojat, M., Louis, D., Maxwell, K., Markham, F., Wender, R. and Gonnella, J.S. (2010) Patient Perceptions of Physician Empathy, Satisfaction with Physician, Interpersonal Trust, and Compliance. International Journal of Medical Education, 1, 83-87. http://dx.doi.org/10.5116/ijme.4d00.b701

[38] Decety, J., Norman, G.J., Berntson, G.G. and Cacioppo, J.T. (2012) A Neurobehavioral Evolutionary Perspective on the Mechanisms Underling Empathy. Progress in Neurobiology, 98, 38-48.

http://dx.doi.org/10.1016/j.pneurobio.2012.05.001

[39] Decety, J. and Svetlova, M. (2012) Putting Together Phylogenetic and Ontogenetic Perspectives on Empathy. Developmental Cognitive Neuroscience, 2, 1-24. http://dx.doi.org/10.1016/j.dcn.2011.05.003

[40] Decety, J. (2011) Dissecting the Neural Mechanisms Mediating Empathy. Emotion Review, 3, 92-108. http://dx.doi.org/10.1177/1754073910374662

[41] Rizzolatti, G., Fogassi, L. and Gallese, V. (2006) Mirrors in the Mind. Scientific American, 295, 54-61. http://dx.doi.org/10.1038/scientificamerican1106-54

[42] Rizzolatti, G. and Sinigaglia, C. (2006) Mirror Neurons. Paidós, Barcelona. http://dx.doi.org/10.1002/0470018860.s00360

[43] Rizzolatti, G., Fogassi, L. and Gallese, V. (2001) Neurophisiological Mechanisms Underlying the Understanding and Imitation of Action. Nature Reviews Neuroscience, 2, 661-670. http://dx.doi.org/10.1038/35090060

[44] García-García, E., González, J. and Maestú-Unturbe, F. (2011) Mirror Neurons and Theory of Mind in the Explanation of Mind. Ansiedad y Estrés, 17, 265-279.

[45] Chambers, D.W. (2010) The Role of Empathy in Ethics (Letter to the Editor). Journal of Dental Education, 74, 1275-1277.

[46] Fernández-Pinto, I., López-Pérez, B. and Márquez, M. (2008) Empathy Theories and Applications in Review. Anales de Psicologia, 24, 284-298.

[47] Almonte, C. and Montt, M.A. (2012) Child and Adolescent Psychopathology. 2nd Edition, Mediterráneo, Santiago, 45-58.

[48] Schwartz, B. and Bohay, R. (2012) Can Patients Help Teach Professionalism and Empathy to Dental Students? Adding Patient Videos to a Lecture Course. Journal of Dental Education, 76, 174-184.

[49] Decety, J., Smith, E., Norman, G.J. and Halpern, J. (2014) A Social Neuroscience Perspective on Clinical Empathy. World Psychiatry, 13, 233-237.

[50] Díaz-Narváez, V.P., Erazo, A.M., Bilbao, J.M., González, F., Padilla, M., Howard, M., et al. (2015) Empathy Gender in Dental Students in Latin America: An Exploratory and Cross-Sectional Study. Health, 7, 1527-1535. http://dx.doi.org/10.4236/health.2015.711166 
Appendix 1. Scale of Physician Empathy (S Version) Adapted to Dental Students in Spanish in Each of the Participating Countries in This Study

\section{ESCALA DE EMPATÍA MÉDICA DE JEFFERzSON (VERSIÓN - S) PARA ESTUDIANTES DE ODONTOLOGÍA}

Instrucciones: Indique su grado de acuerdo o desacuerdo con cada una de las siguientes afirmaciones encerrando en un círculo el número apropiado después de cada afirmación. Utilice la escala de 7 puntos (un mayor número indica un mayor acuerdo):

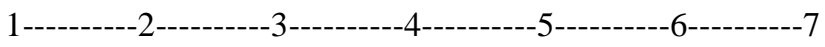

\section{Totalmente en desacuerdo Totalmente de acuerdo}

1. La comprensión que tenga el odontólogo de los sentimientos del paciente y de su familia no influye en el tratamiento.

2. Los pacientes se sienten mejor cuando el odontólogo comprende sus sentimientos.

$\begin{array}{lllllll}1 & 2 & 3 & 4 & 5 & 6 & 7\end{array}$

3. Es difícil para el odontólogo ver las cosas desde la perspectiva de su paciente.

$\begin{array}{lllllll}1 & 2 & 3 & 4 & 5 & 6 & 7\end{array}$

4. La comprensión del lenguaje corporal es tan importante como la comunicación verbal en la relación odontólogo - paciente.

5. El buen sentido del humor del odontólogo contribuye a tener un mejor resultado clínico.

$\begin{array}{lllllll}1 & 2 & 3 & 4 & 5 & 6 & 7\end{array}$

6. Debido a que la gente es diferente, es difícil ver las cosas desde el punto de vista del paciente.

$\begin{array}{lllllll}1 & 2 & 3 & 4 & 5 & 6 & 7\end{array}$

7. Prestar atención a las emociones del paciente no es importante durante la anamnesis o historia clínica.

$\begin{array}{lllllll}1 & 2 & 3 & 4 & 5 & 6 & 7\end{array}$

$\begin{array}{lllllll}1 & 2 & 3 & 4 & 5 & 6 & 7\end{array}$

8. Prestar atención a las experiencias personales del paciente no influye en los resultados del tratamiento.

$\begin{array}{lllllll}1 & 2 & 3 & 4 & 5 & 6 & 7\end{array}$

9. Los odontólogos deberían tratar de ponerse en el lugar del paciente cuando lo atienden.

$\begin{array}{lllllll}1 & 2 & 3 & 4 & 5 & 6 & 7\end{array}$

$\begin{array}{llllllll}1 & 2 & 3 & 4 & 5 & 6 & 7\end{array}$

10. Los pacientes valoran que el odontólogo entienda sus sentimientos, lo cual es terapéutico por sí mismo.

$\begin{array}{lllllll}1 & 2 & 3 & 4 & 5 & 6 & 7\end{array}$

11. La enfermedad del paciente puede ser curada solamente por el tratamiento odontológico; por lo tanto, los lazos emocionales del médico con su paciente no tienen influencia significativa en el tratamiento odontológico.

12. Preguntarle a los pacientes acerca de sus vivencias personales, no es de ayuda para comprender sus dolencias físicas.

13. Los odontólogos deberían tratar de comprender lo que está sucediendo en la mente de los pacientes, poniendo atención a la comunicación no verbal y al lenguaje corporal.

14. Yo creo que las emociones no tienen lugar en el tratamiento de la enfermedad odontológica.

$\begin{array}{lllllll}1 & 2 & 3 & 4 & 5 & 6 & 7\end{array}$

15. La empatía es una habilidad terapéutica sin la cual el éxito del odontólogo puede estar limitado.

16. La comprensión que tenga el odontólogo del estado emocional de su paciente, así como también de su familia, es un componente importante de la relación médico - paciente.

17. Los odontólogos deberían pensar como sus pacientes para poder darles un mejor cuidado.

18. Los odontólogos no deberían dejarse influenciar por lazos personales fuertes entre sus pacientes y los miembros de sus familias.

19. No disfruto leer literatura no odontológica o de arte.

$\begin{array}{lllllll}1 & 2 & 3 & 4 & 5 & 6 & 7\end{array}$

$\begin{array}{lllllll}1 & 2 & 3 & 4 & 5 & 6 & 7\end{array}$

$\begin{array}{lllllll}1 & 2 & 3 & 4 & 5 & 6 & 7\end{array}$

$\begin{array}{lllllll}1 & 2 & 3 & 4 & 5 & 6 & 7\end{array}$

$\begin{array}{lllllll}1 & 2 & 3 & 4 & 5 & 6 & 7\end{array}$

$\begin{array}{lllllll}1 & 2 & 3 & 4 & 5 & 6 & 7\end{array}$

$\begin{array}{lllllll}1 & 2 & 3 & 4 & 5 & 6 & 7\end{array}$

$\begin{array}{lllllll}1 & 2 & 3 & 4 & 5 & 6 & 7\end{array}$

20. Creo que la empatía es un importante factor terapéutico en el tratamiento médico.

$\begin{array}{lllllll}1 & 2 & 3 & 4 & 5 & 6 & 7\end{array}$ 